The Common Agricultural Policy of the European Union the present and the future

EU Member States

point of view 



\section{INSTITUTE OF AGRICULTURAL AND FOOD ECONOMICS NATIONAL RESEARCH INSTITUTE}

\section{The Common Agricultural Policy of the European Union - the present and the future}

\section{EU Member States point of view}

Editors:

dr Marek Wigier

prof. dr hab. Andrzej Kowalski

Proceedings of the International Scientific Conference

"The Common Agricultural Policy of the European Union - the present and the future" Multi-Annual Programme 2015-2019

"The Polish and the EU agricultures 2020+. Challenges, chances, threats, proposals" 5-7 December 2017 Stare Jabłonki, Poland

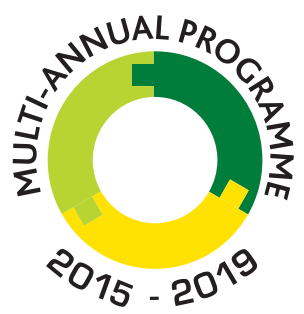

THE POLISH AND THE EU AGRICULTURES 2020+ CHALLENGES, CHANCES, THREATS, PROPOSALS

Warsaw 2018 
This monograph was prepared under the Multi-Annual Programme 2015-2019

"The Polish and the EU agricultures 2020+. Challenges, chances, threats, proposals".

The publication is a collection of selected papers delivered at the 22th edition of the International Scientific Conference organized by the Institute of Agricultural and Food Economics - National Research Institute. The theme of the conference was "The Common Agricultural Policy of the European Union the present and the future. The conference was placed on 5-7 December 2017 in Stary Jabłonki in Poland. Common Agricultural Policy was and still is one of the key pillars of European integration. Published in two volumes materials refer directly to the current and future of the CAP in EU and non EU member states, the strategic objectives and principles of agricultural policy for the agri-food sector and rural areas, address the issues of equilibrium between agriculture, forestry and land use, relate to the dilemmas for the EU budget and the CAP after 2020, CAP instruments and their adjustment, transformations of the rural economy and programming of the rural and agricultural policy, as well as productivity and production efficiency and tensions between sectoral action and between different models of territorial activities.

In the Scientific Committee of the Conference was participated: Prof. Andrzej Kowalski (IAFE-NRI, Poland), Prof. Drago Cvijanonivić (University of Kragujevac, Serbia), Prof. Thomas Doucha (IAEI, Czech Republic), Noureddin Driouech, PhD (CIHEAM, Italy), Prof. Szczepan Figiel (IAFE-NRI, Poland), Prof. Masahiko Gemma (Waseda University, Japan), Prof. Wojciech Józwiak (IAFE-NRI, Poland), Prof. Jacek Kulawik (IAFE-NRI, Poland), Prof. Yuriy Oleksiyovych Lupenko (IAE, Ukraina), Prof. Věra Majerová (CULS, Prague), Prof. Dimitre Nikolov (IAE, Bulgaria), Maire Nurmet, PhD (EMÜ, Estonia), Prof. Gabriel Popescu (ASE, Romania), Norbert Potori, PhD (AKI, Hungary), Prof. Włodzimierz Rembisz (IAFE-NRI, Poland), Piotr Szajner, PhD (IAFE-NRI, Poland), Prof. Alina Sikorska (IAFE-NRI, Poland), Prof. Jonel Subić (IAE, Serbia), Prof. Samuele Trestini (UNIPD, Italy), Prof. Olga Varchenko (Bila Tserkva National Agrarian University, Ukraine), Dipl.-Ing. Klaus Wagner (AWI, Austria), Marek Wigier, PhD (IAFE-NRI, Poland), Prof. Józef St. Zegar (IAFE-NRI, Poland)

In the Organising Committee of the Conference was participated: Małgorzata Bułkowska (IAFE-NRI, Poland), Anna Hankiewicz (IAFE-NRI, Poland), Joanna Jaroszewska (IAFE-NRI, Poland), Joanna Korczak (IAFE-NRI, Poland), Krzysztof Kossakowski (IAFE-NRI, Poland), Irena Mikiewicz (IAFE-NRI, Poland), Małgorzata Mikołajczyk (IAFE-NRI, Poland), Lech Parzuchowski (IAFE-NRI, Poland), Ewa Sierakowska (IAFE-NRI, Poland), Paulina Smakosz (IAFE-NRI, Poland), Leszek Ślipski (IAFE-NRI, Poland), Marek Wigier, PhD (IAFE-NRI, Poland).

Reviewers:

Professor Dimitre Nikolov, Institute of Agricultural Economics, Sofia, Bulgaria

Professor Gabriel Popescu, The Bucharest University of Economic Studies, Bucharest, Romania

Professor Samuele Trestini, University of Padva, Italy

Proofreader

Katarzyna Mikulska

Technical editors:

Joanna Jaroszewska, Barbara Pawtowska, Ewa Sierakowska, Kamila Tomaszewska,

Barbara Walkiewicz

Translated by

Summa Linguae S.A.

Cover Project

Leszek Ślipski

ISBN 978-83-7658-743-1

DOI: $10.30858 / \mathrm{pw} / 9788376587431$

Instytut Ekonomiki Rolnictwa i Gospodarki Żywnościowej

- Państwowy Instytut Badawczy

ul. Świętokrzyska 20, 00-002 Warszawa

tel.: (22) 5054444

faks: (22) 5054636

e-mail:dw@ierigz.waw.pl

http://www.ierigz.waw.pl 


\section{Contents}

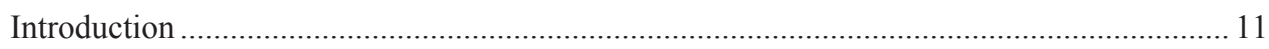

Dr Marek Wigier

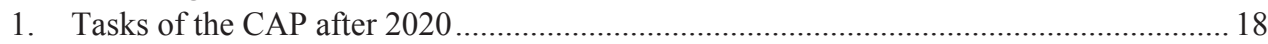

Dr hab. Julian Krzyżanowski

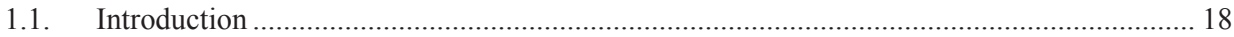

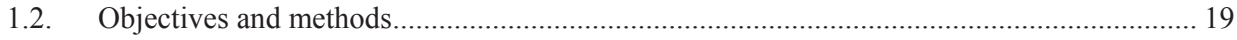

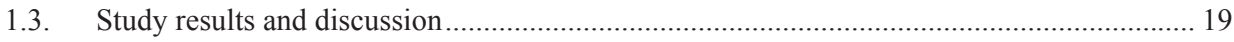

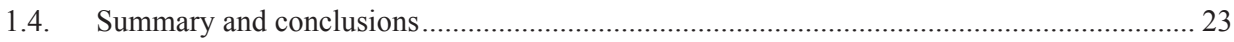

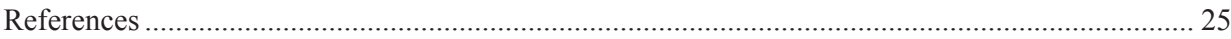

2. An assessment of the regional impacts of post-2020 CAP budgetary cuts on production

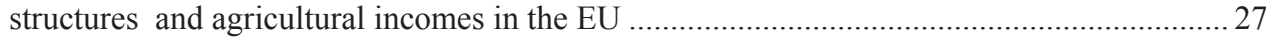

PhD Norbert Potori, PhD János Sávoly, PhD Szabolcs Biró

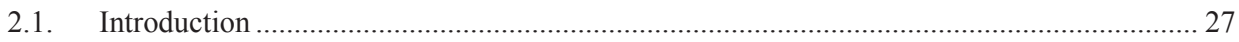

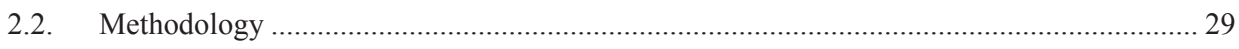

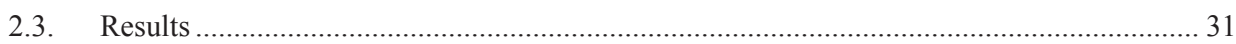

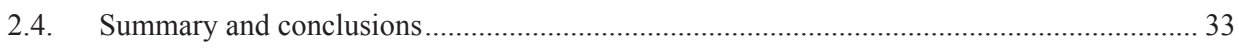

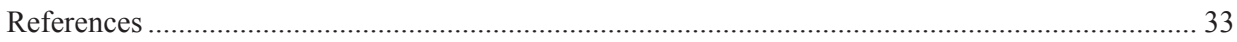

3. Is there room for financial instruments in the Common Agricultural Policy? Casus of

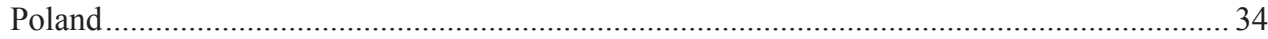

Prof. dr hab. Jacek Kulawik, PhD Barbara Wieliczko, PhD Michat Soliwoda

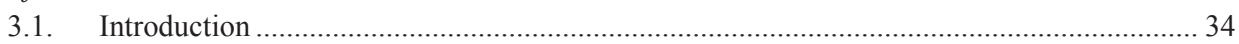

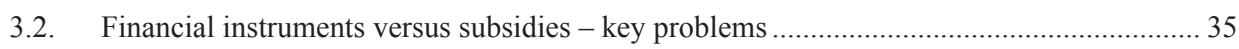

3.3. The use of financial instruments under the EU policy ......................................................... 37

3.4. Example of the use of FI in the 2014-2020 programming period ......................................... 38

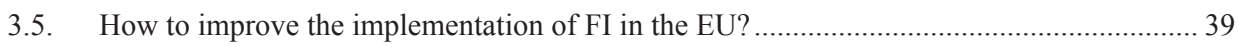

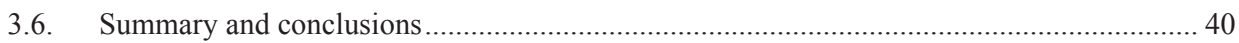

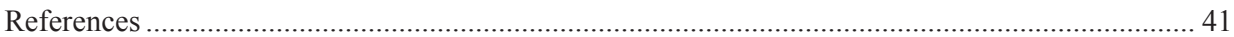

4. The past, present and future of the CAP - the Hungarian viewpoint ............................. 43

Dr Tamás Mizik

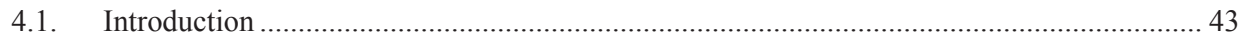

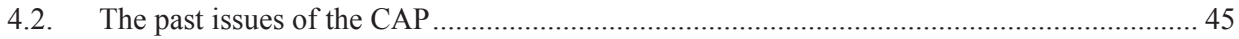

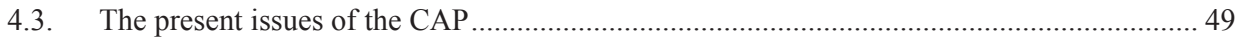

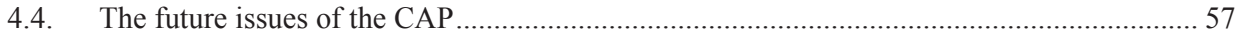

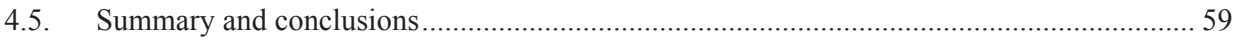

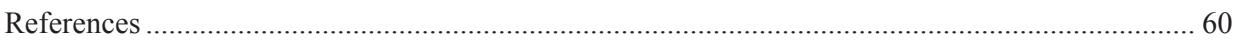


5. Going beyond the Rural Development Programme: a Master Plan for Austria's rural areas in the framework of the CAP

Dip.-Ing. Klaus Wagner

5.1. Introduction

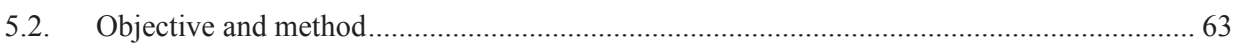

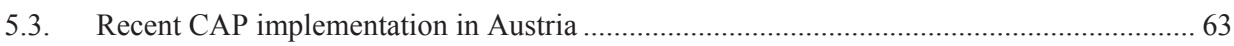

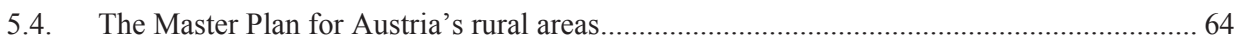

5.5. CAP in the system of the EU policy objectives and in the view of regional science

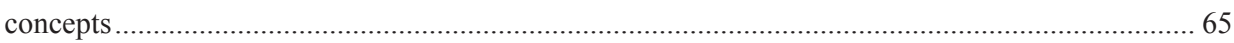

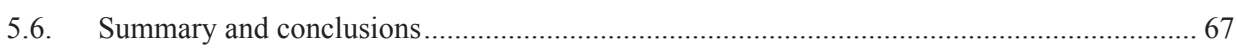

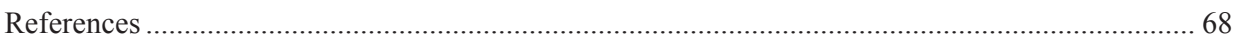

6. Possibilities to connect the Romanian agricultural research to the market requirements 69 Prof. Gabriel Popescu

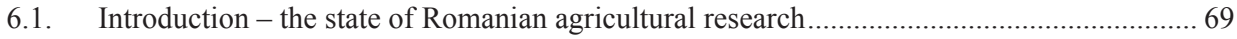

6.2. The problems faced by agricultural research since 1990 ..................................................... 71

6.3. Possible solutions for the recovery of Romanian agricultural research ................................ 76

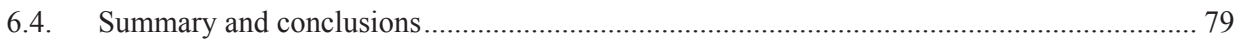

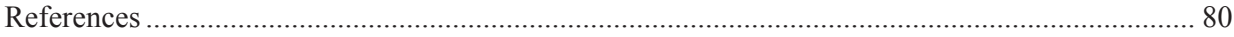

7. Price relationships of the production factors as exogenous determinants of production in agriculture.

Prof. dr hab. Włodzimierz Rembisz, PhD Adam Waszkowski

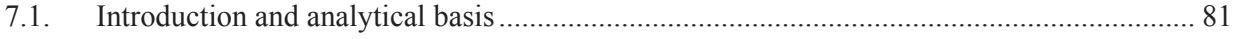

7.2. Relationships of prices of the capital, labour and land factors - hypothetical approach...... 83

7.3. Relationships of prices of the capital, labour and land factors - empirical approach .......... 84

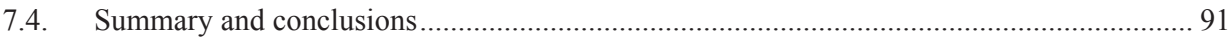

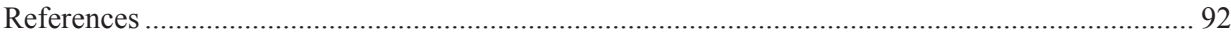

8. Effects of direct payments on agricultural development in Bulgaria ............................. 93 PhD Bozhidar Ivanov

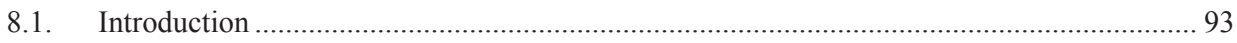

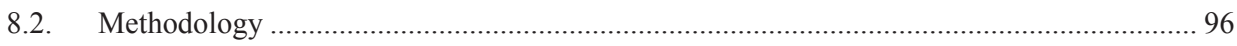

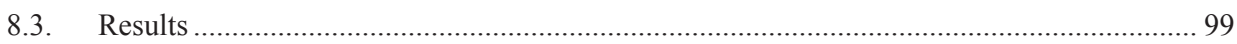

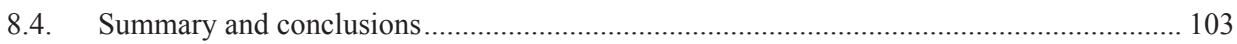

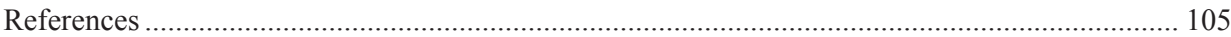

9. Re-adjusting risk management within the CAP: evidences on the implementation of the

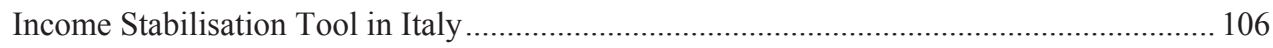
Prof. Samuele Trestini, PhD Elisa Giampietri

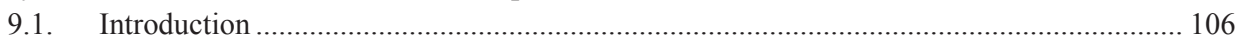

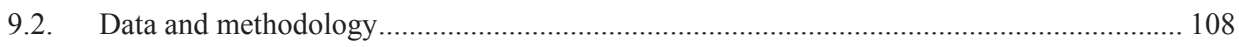




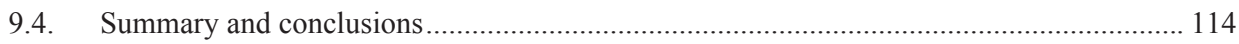

References

10. Comparison of risk management tools under the CAP of the EU, the US Farm Bill

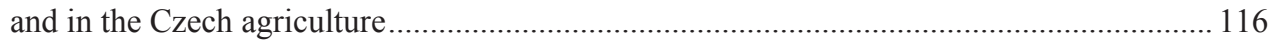
Ing. Václav Vilhelm, CSc., Ing. Sumudu Namali Gouri Boyinová, PhD Jindřich Špička

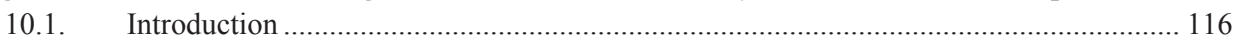

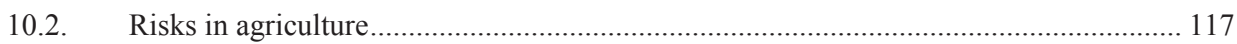

10.3. Risk management policy in the United States Farm Bill 2014 _..................................... 118

10.4. Risk management policy of the European Union's CAP ................................................ 119

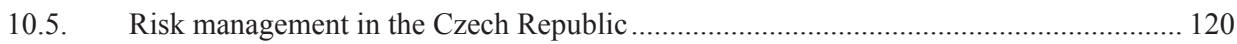

10.6. Comparative analysis of risk management policies ........................................................ 121

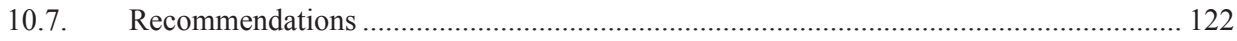

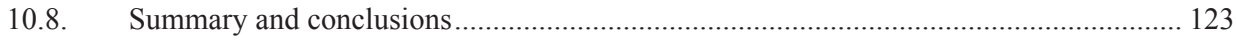

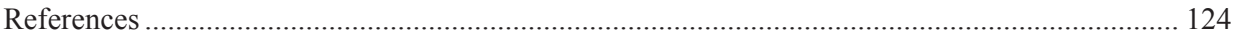

11. Factors determining the crop insurance level in Poland taking into account the level

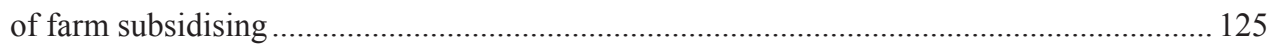

Prof. Adam Was, PhD Pawet Kobus

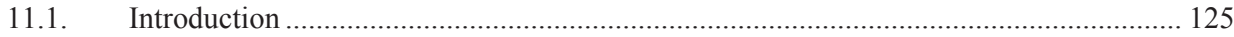

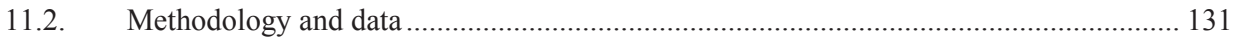

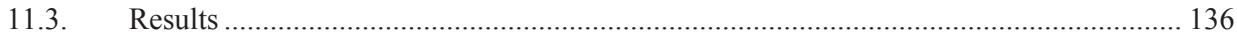

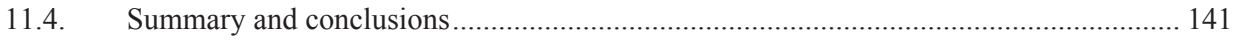

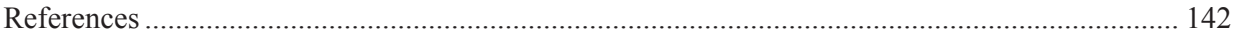

12. Farms and agricultural enterprises for development of sustainable and smart cooperatives: a multifactor approach using digital farm management ............................... 147 Prof. dr habil Adriana Mihnea, Prof. dr Dimitre Nikolov, dr Krasimir Kostenarov

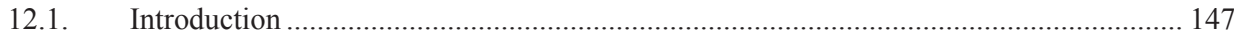

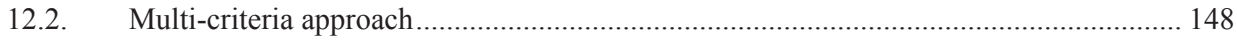

12.3. Construction of Farm Management Model ................................................................ 150

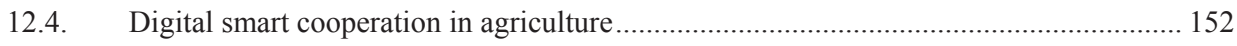

12.5. Application of the ANP Farm Management Model ....................................................... 154

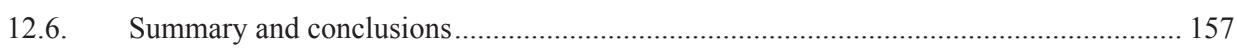

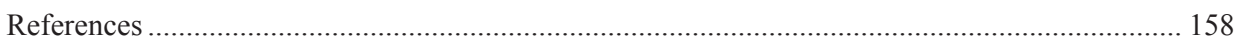

13. Brexit - potential implications for the Polish food sector .............................................. 159

Dr Katarzyna Kosior, Dr Łukasz Ambroziak

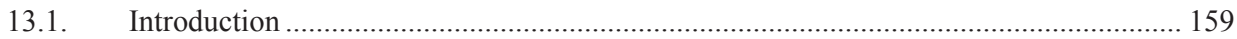

13.2. Negotiations on Brexit - what should be the model of the future relations? ..................... 161

13.3. The future of the EU finances and the CAP in the context of Brexit .............................. 163 
13.4. Impact of possible changes in the CAP budget on the net balance of Poland and transfers to the Polish agriculture.

13.5. The potential impact of Brexit on agri-food trade between Poland and the United

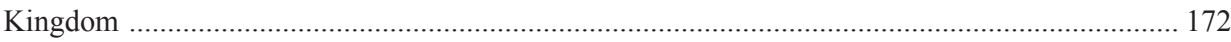

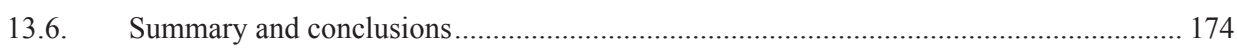

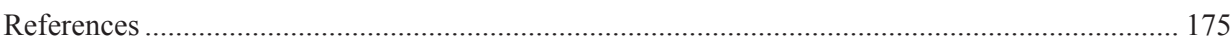

14. The Transatlantic Trade and Investment Partnership (TTIP): a threat or an opportunity for the EU-Mediterranean agriculture and agri-food sector? An exploratory survey ........... 177 Dipl.-Ing. Katja Pietrzyck, PhD Noureddin Driouech, Prof. Brigitte Petersen

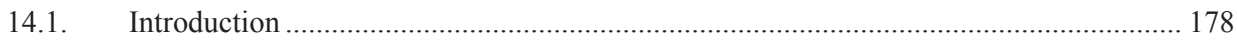

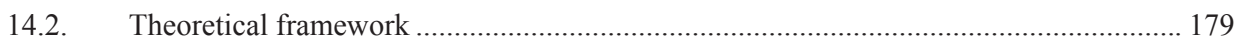

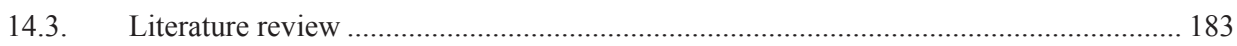

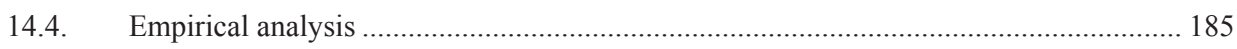

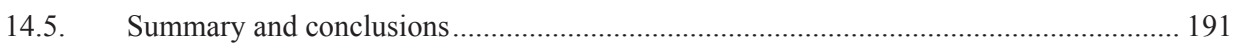

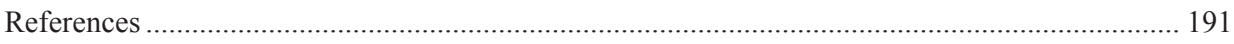

Appendix I: Overview of trade statistics regarding selected products ........................................... 195

15. The concept of short supply chains in the food economy............................................. 196

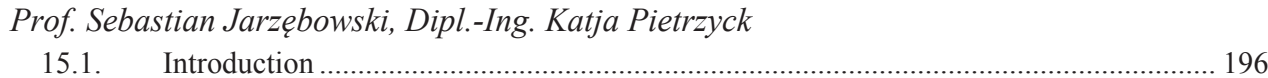

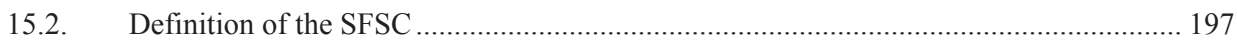

15.3. Development of short supply chains in Europe............................................................. 201

15.4. Global context of European short supply chains ........................................................... 205

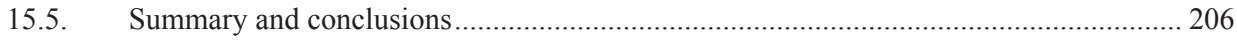

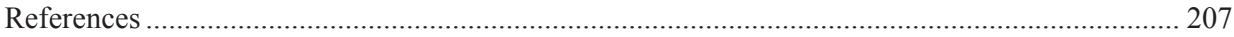

16. The CAP implementation in Wallonia - today performance and questions for the future -

A brief supplementary comment from Warmia and Mazury perspective............................. 209

PhD Philippe Burny, PhD Benon Gazinski

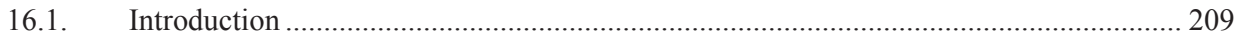

16.2. Implementation of the green payment in Wallonia in 2015 ........................................ 210

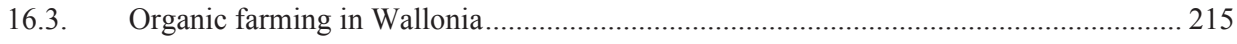

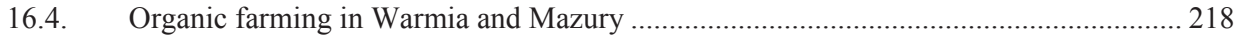

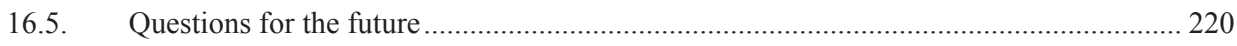

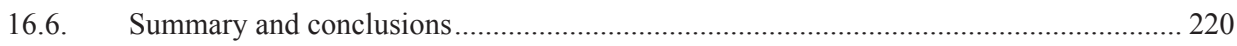

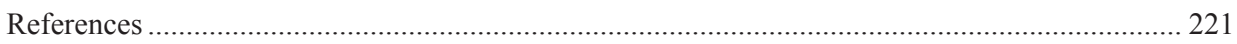

17. Afforestation of agricultural land financed from the RDP 2014-2020 ....................... 224

PhD Marek Zieliński

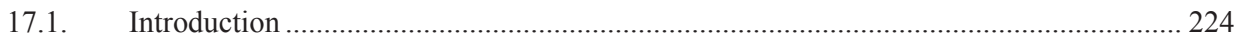

17.2. Natural farming conditions in Poland in regional terms................................................. 225 
17.3. The impact of natural farming conditions in Poland on the economic situation and the possibility of afforestation on farms

17.4. Land afforestation financed from the RDP 2014-2020 in regional terms

17.5. Importance of land afforestations financed under the RDP 2014-2020 in the EU climate policy for 2021-2030.

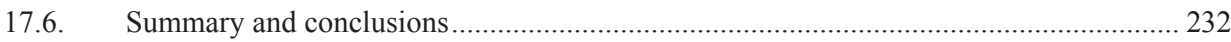

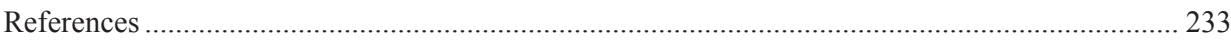

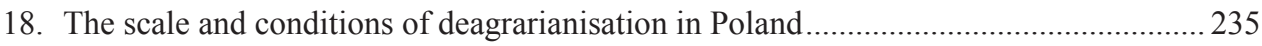

PhD Michat Dudek, PhD Bożena Karwat-Woźniak

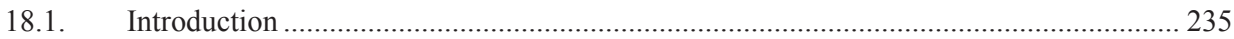

18.2. The conditions of the decrease in employment in agriculture ......................................... 236

18.3. The change in the scale of employment in agriculture in Poland and its conditions....... 238

18.4. The instruments of the Cohesion Policy and agriculture and rural development of the EU

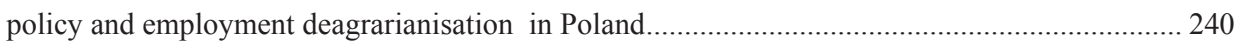

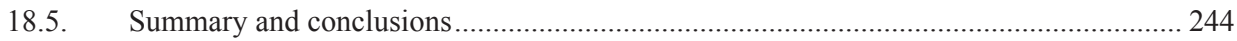

References 245

19. Socio-economic and environmental parameters and results of rural development under the CAP: the case of Bulgaria ................................................................................................ 247 Prof.dr.hab. Julia Doitchinova, Prof.dr.hab. Ivan Kanchev, Ass.Prof. Ralitsa Terziyska PhD, Ass.Prof. Kristina Todorova PhD

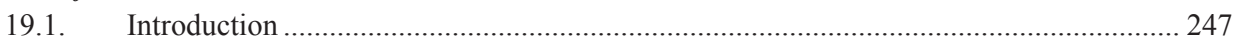

19.2. Changes in Bulgarian rural areas - socio-economic and environmental aspects................ 248

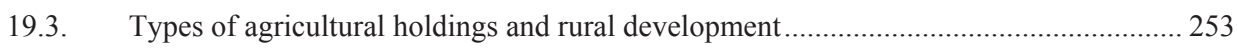

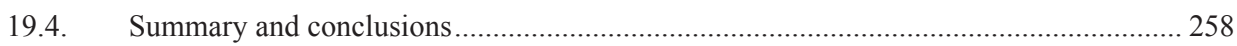

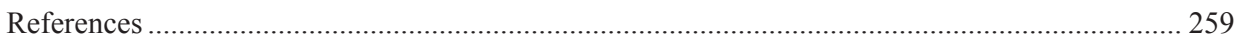

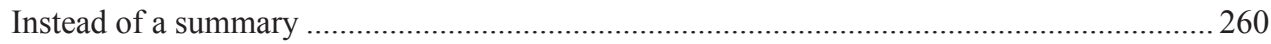

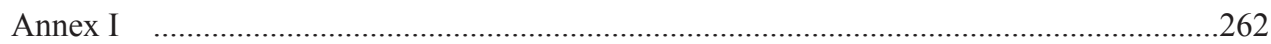




\title{
10. Comparison of risk management tools under the CAP of the EU, the US Farm Bill and in the Czech agriculture ${ }^{15}$
}

\author{
Ing. Václav Vilhelm, CSc., Ing. Sumudu Namali Gouri Boyinová, \\ PhD Jindřich Špička,
} Institute of Agriculture Economics and Information, Prague 2, Czech Republic vilhelm.vaclav@uzei.cz,Boyinova.Sumudu@uzei.cz,Spicka.Jindrich@uzei.cz

DOI: $10.30858 / \mathrm{pw} / 9788376587431.10$

\begin{abstract}
It is due to its strong dependence on the market and natural factors, such as weather conditions and extreme weather events or livestock diseases, agriculture is characterized by high exposure to risks. It is the reason for the important role of mitigation of their impacts in the framework of agricultural politics of many countries of the world. The presentation analyses the various systems of risk management tools in the agricultural policy of the EU, the US and the Czech Republic. In the US the support of risk management tools such as the crop and income insurance is the most important part of the policy. In the CAP of the EU, the support for agricultural insurance plays only a minor role and this support is usually applied on the national level. It is also the case of the Czech agriculture, which is characterized by the prevalence of large corporate farms. This structure creates the important barrier for reasonable application of the risk management tools under the RDP for the period bewee 2013 and 2020.
\end{abstract}

Keywords: risk management, comparative analysis, risk management tools, Common Agriculture Policy of the Eu, US Farm Bill

JEL codes: Q18, Q14, H12, H84

\subsection{Introduction}

This paper attempts to compare risk management policies applied in the United States' Agricultural Act (Farm Bill), the European Union's Common Agricultural Policy (CAP), and in the Czech Republic on the national level [Vilhelm et al., 2015]. The findings presented in the literature review should contribute to the formulation of requirements for future risk management policy and its effective application in the conditions of the Czech agriculture in the context of the EU's CAP.

\footnotetext{
${ }^{15}$ This paper was supported by the Internal Project of the Institute of Agriculture Economics and Information, Project no. 1115 "Comparative Analysis of Risk Management Tools: The United States, the European Union, and the Czech Republic” (Řizení rizik v zemědělství - srovnání situace v USA, EU a ČR).
} 
The work draws mainly from the studies by Mathijs [2017] and Cordier [2015], which describe the current agricultural risk management under the EU's CAP for 2014-2020 and the US Farm Bill of 2014. Furthermore, it also makes recommendations for the future formulation of the CAP risk management policy drawing from the above-mentioned studies.

The Common Agricultural Policy (CAP) of the European Union (EU) has historically been undergoing a series of reforms that have contributed to its current form. The current CAP reform after 2020 is likely to bear a gradual reduction in the income support with the intention, e.g. to shift financial resources to risk management systems [Cordier, 2015]. The general market orientation of the European agriculture since the mid-1990s and recent liberalization in the milk (dairy) and sugar sector has put European farmers at increased risk, thus increasing the CAP's demand for more effective price volatility and other risks. The current task is to review and improve the position of farmers in supply chains and to make recommendations such as: to increase market transparency, to make risk management tools more attractive by simplifying loss calculations and the possibility to reimburse and relocate resources from unplanned direct payments to rescue networks for farmers who can use them at a time of market imbalance [Agricultural Markets Task Force, 2016]. The transfer of resources should focus on introducing an integrated risk management strategy at the EU level complementing existing Member States' strategies, not only as a freely defined set of strategies but also as a structured and coherent framework complementing both private and public risk management measures. Such a framework should provide a reasonable response to the various threats posed by producers.

In the US, agricultural policy has seen a shift from direct payments used as a basic supporting tool for agricultural income-generating programmes, both natural and price character. This approach is, therefore, fundamentally different from the approach of agricultural support implemented in the EU's CAP.

\subsection{Risks in agriculture}

The Organization for Economic Co-operation and Development analyses three layers of risks: high frequency/ low damage normal risks, low frequency/ high damage catastrophic risks, and marketable risks with immediate levels of frequency and damage [OECD, 2011]. Normal risks are managed by farmers as a part of the normal business strategy - small accidents, minor management failures, normal weather volatility. Marketable risks are handled through market tools (insurance, future markets, cooperative arrangements among farmers - with or without support from public sources). Catastrophic risks are handled through market tools with public support or directly by the state through government interventions. 
Figure 1. Optimal pattern of risk management strategies and policies

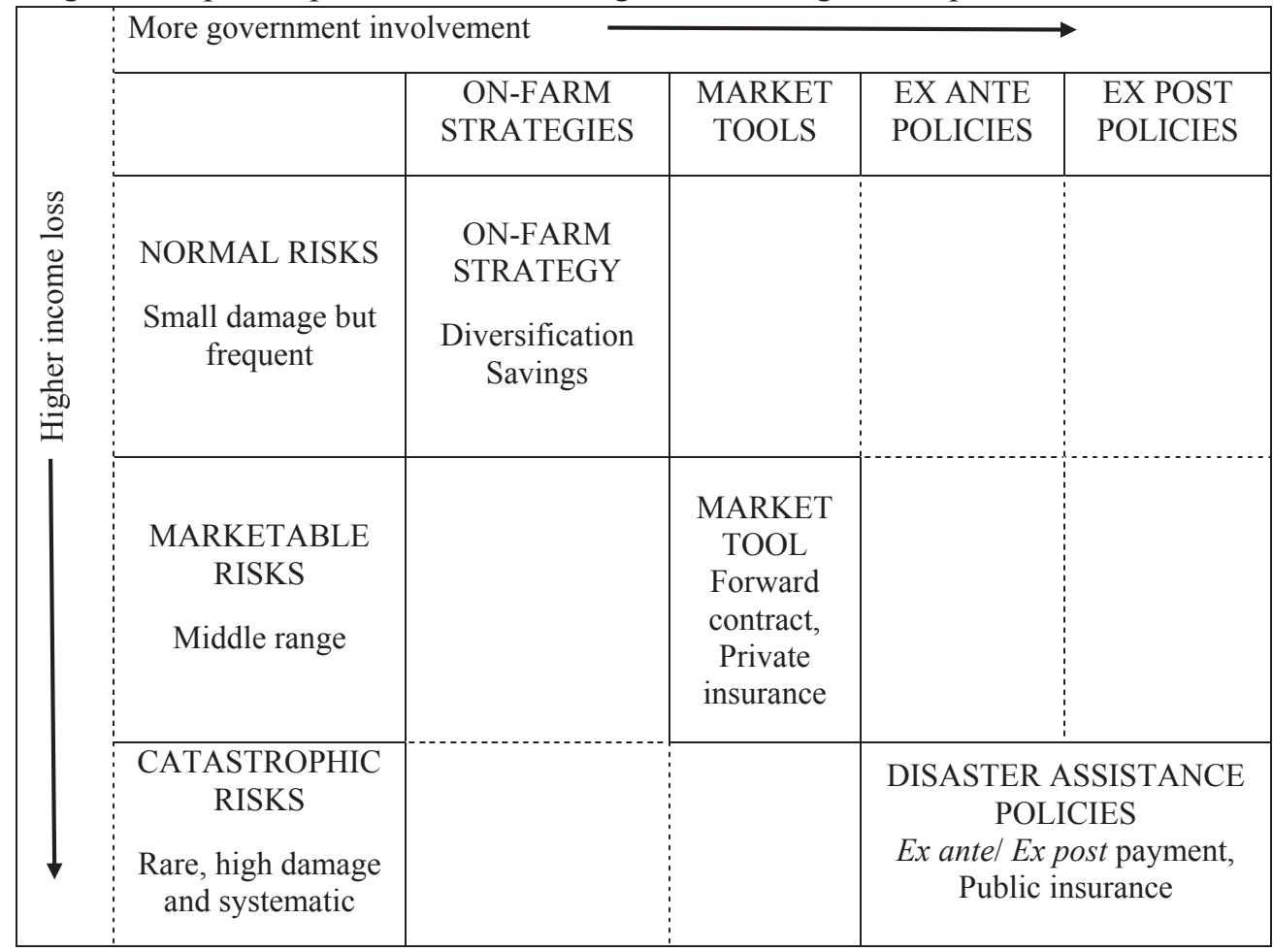

Source: OECD (2011), own processing.

\subsection{Risk management policy in the United States Farm Bill 2014}

The US agricultural policy is established by the Agriculture Acts. The long-term objectives and priorities were and are ensuring and maintaining food security in the US, ensuring stable income and income for farmers, stabilizing agrarian markets, deepening the relationship to the environment. This law was introduced as the Farm Bill, which sets the US agricultural policy for a five-year period. The Farm Bill is approved by the Congress and the Senate of Representatives. Both producers, consumers, and taxpayers share their views with views of the aforementioned authorities. The first Farm Bill was introduced in 1949 and did not bring any major changes. The programme for food consumption, environmental protection and the recently approved programme on bioenergy has been developed over the last decade [Bureau, 2012].

Programmes focused on selected commodities were shifted from direct payments to two main instruments: Agriculture Risk Coverage (ARC) revenue programme and Price Loss Coverage (PLC) programme. The ARC can be based on coverage of individual or district earnings. Payment is paid out if yields fall below $86 \%$ of the benchmark yields. The PLC is a form of a counter-cyclical programme that pays to farmers when market prices fall below a set reference price [Cordier, 
2015]. Farmers with the so-called "basic acres" had to choose to register in the ARC or the PLC in 2014. These programmes pay only for basic acres and farmers must respect certain conservation objectives. All in all,75\% of base hectares were included in ARC and 22\% in PLC [Johansson, 2016]. For dairy farmers, there is a Dairy Margin Protection Plan (DMPP) based on milk prices and feed prices.

Crop insurance programmes include premiums paid by farmers. Each year, farmers can choose the acres to be covered by crops, whether net income (AYP) or gross income (ARP) and coverage. The reference net and gross revenues are set at the district level. These programmes require farmers to comply with the conservation criteria. Most farmers enrolled in the protection of gross income $(70.3 \%)$ than demand protection of net income (21.0\%) [Johansson, 2016].

\subsection{Risk management policy of the European Union's CAP}

Since 1993, the Common Agricultural Policy has significantly changed its approach to supporting agricultural markets. Strict price and supply controls were replaced by market orientation principles and direct payments. Market measures were maintained, but for most commodities, they are long-term inactive and can be applied in exceptional circumstances. A crisis reserve was set up. Support was provided to insurance and mutual funds. However, these instruments are unevenly used by the Member States [Špička and Vilhelm, 2012]. Despite the new risk management tools mentioned above, the development of recent years was shaken by the crisis period, the agricultural sector so much that doubts arose as to whether the new EU's CAP is capable of coping with market disruption [Cordier, 2015].

Risk management systems in the EU have not yet been established, particularly in terms of income stabilization. Instruments covering natural hazards could, due to their frequent local character, be classified in the second pillar in Regulation (EU) No. 1305/2013 of the European Parliament and of the Council of 17 December 2013 on support for rural development by the European Agricultural Fund for Rural Development (EAFRD). Regulation (EU) No. 1305/2013 of the European Parliament and of the Council in Articles from 36 to 39 presents the measures related to farm risk management. Article 36, equivalent to Article 68 in Council Regulation (EC) No. 73/2009 of 19 January 2009 establishing common rules for direct support schemes for farmers under the common agricultural policy and establishing certain support schemes for farmers, deals with risk management in general. The three following articles deal respectively with subsidies for agricultural insurance (Article 37: Crop, animal, and plant insurance) and mutual funds (Article 38: Mutual funds for adverse climatic events, animal and plant diseases, pest infestations and environmental incidents), and with Income stabilization tool (Article 39). However, the management and regulation of price risks are too closely linked to market measures and cannot, therefore, be created, financed and controlled within the framework of subsidiarity. 
The main tools are particularly participation in income stabilization programmes, preventive savings or risk reduction due to diversification. The possibilities for intervention for agricultural products are limited, except for products such as fruit and vegetables for which the volatility is extremely high due to natural external causes. The EU's for CAP 2014-2020 has clearly positioned risk management measures in rural development, i.e. in Regulation No. 1305/2013, and no longer on farm income support as was previously the case. The shift is clear, risk management instruments moved from the first to the second pillar. Consequently, they remain as facultative instruments for the MSs. This optional implementation by the MSs will inevitably lead to the discordant development and, probably, economic distortions of this new toolkit. Furthermore, risk management policy is marginal within the text of Regulation No. 1305/2013. Qualitatively, risk management issues do not seem to be a priority for rural development either. In practice, Rural Development Programme (RDP) measures have been implemented in only 13 of more than 100 rural development programmes within the EU.

\subsection{Risk management in the Czech Republic}

Articles 36-39 of Regulation No. 1305/2013 of the European Parliament and of the Council are not implemented in the Czech Rural Development Programme. It is caused by a criterion for the compensation which requires at least a $30 \%$ loss compared to the production average of the last 3 years (or an average of 3 years from the last 5 years with the exclusion of the minimum and maximum), and given the size of the Czech farms (hectare-weighted median ${ }^{16}$ of 1100 hectares).

In 2016, agricultural insurance was offered by seven commercial insurance companies in the Czech Republic according to the Report on Agriculture of the Czech Republic in 2016 [Zpráva o stavu zemědělství, 2016]. Agricultural insurance companies offer commercial insurance products such as crop and livestock insurance that relate to selected natural hazards, disease risks, and possibly other risks connected to crop and livestock production. Some risks remain uninsurable in the Czech Republic, in addition to price risks. Those are for example the risks of drought and rain during the harvest period. The interface between insurable and uninsurable risks lies above all in the current supply and purchase demand for products to cover a certain risk and may change over time. As part of the subsidized insurance programme, PGRLF [Subsidiary and Guarantee Agricultural and Forestry Fund) offers support for crop and livestock insurance since 2004. The level of support was maximally $50 \%$ of the premium paid for crops or livestock insurance. The aid is granted to agricultural business entities

\footnotetext{
${ }^{16}$ The hectare-weighted median is calculated by ordering farms from the smallest to the largest and choosing the farm size at the middle hectare. Thus, half of all agricultural land is on farms smaller than the median and the other half is operated by farms greater than the hectare-weighted median.
} 
fulfilling the parameters of a small or medium-sized enterprise. In 2016, nearly $60 \%$ of the crop area and about $80 \%$ of animals were insured.

The damages caused by uninsurable risks, mainly draught, are usually compensated by ad hoc state aid. Consideration is being given to the establishment of the Fund for uninsurable risks, which has already been authorized by the European Commission and the notification is valid until 2022. However, the legislative issues and prerequisites for its functioning have not been satisfactorily resolved.

\subsection{Comparative analysis of risk management policies}

Agriculture income in the US is historically supported by compensatory payments that tend to stabilize incomes and leave the market to its natural variability. Farmers are responsible for individual price risk management by using time trades as well as engaging in rescue networks. Farm Bill 2014 focuses on ex ante risk management tools structured by safety net measures. Fixed direct payments are not implemented.

Table 1. Risk management comparison (the US, the EU, the CZ)

\begin{tabular}{|c|c|c|c|c|}
\hline & Area & $\mathbf{E U}$ & US & $\mathbf{C Z}$ \\
\hline \multirow{6}{*}{ 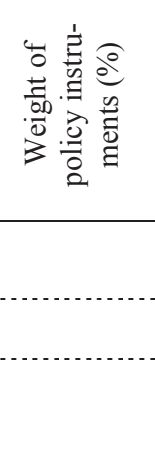 } & Insurance & $1 \%$ & $60 \%$ & $1.25 \%$ \\
\hline & Safety nets & $30 \%$ & $40 \%$ & Approx. $30 \%$ \\
\hline & $\begin{array}{l}\text { Income support/ } \\
\text { direct payments }\end{array}$ & $60 \%$ & $0 \%$ & Approx. $60 \%$ \\
\hline & Policy & Static-segmented & Dynamic-integrated & Static-segmented \\
\hline & Budget & Fixed & Flexible & Mostly fixed \\
\hline & $\begin{array}{c}\text { Risk management } \\
\text { support }\end{array}$ & $\begin{array}{l}\text { Agricultural } \\
\text { income support }\end{array}$ & $\begin{array}{l}\text { Agricultural income } \\
\text { risk management }\end{array}$ & $\begin{array}{c}\text { Agricultural income } \\
\text { support }\end{array}$ \\
\hline \multirow{3}{*}{ 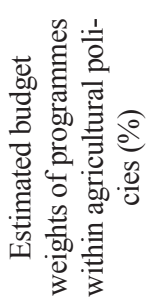 } & $\begin{array}{l}\text { Risk management } \\
\text { support }\end{array}$ & $1 \%$ & $47 \%$ & $1 \%$ \\
\hline & Safety nets & $5 \%$ & $23 \%$ & $2 \%$ \\
\hline & $\begin{array}{l}\text { Income support/ } \\
\text { direct payments }\end{array}$ & $72 \%$ & $0 \%$ & $72 \%$ \\
\hline
\end{tabular}

Source: [Cordier, 2015], own processing.

The EU's CAP 2014-2020 concentrates most of its resources on fixed direct payments - reduces their compensatory role in lowering prices and supporting farm incomes, greening - encourages sustainable agriculture that produces improved public goods (food quality, environment, and measures against climate change). 
Safety nets are included, but to a limited extent and with limited financial capacities. The European Union's safety nets and risk management tools are now being defined, implemented and managed separately under the two pillars of the CAP. Table 1 shows the differences between the risk management policies in the EU's CAP, the US Farm Bill, and the Czech Republic.

\subsection{Recommendations}

Table 2. Recommendations

\begin{tabular}{|c|c|c|}
\hline ISSUES & CRITICAL POINTS & $\begin{array}{l}\text { RECOMMENDATIONS / } \\
\text { PROPOSALS }\end{array}$ \\
\hline $\begin{array}{l}\text { The EU public and private } \\
\text { partnership }\end{array}$ & $\begin{array}{l}\text { Absence of coordination between } \\
\text { public safety nets and private risk } \\
\text { management tools }\end{array}$ & $\begin{array}{l}\text { Build on common parameters for } \\
\text { defining layers of risk. Improvement } \\
\text { of risk valuation and premium pricing }\end{array}$ \\
\hline $\begin{array}{c}\text { Risk coverage in between } \\
\text { "normal" and "catastrophic" } \\
\text { risks }\end{array}$ & $\begin{array}{l}\text { Discontinuity between financial } \\
\text { and insurance markets }\end{array}$ & $\begin{array}{l}\text { Support of hybrid OTC contracts and } \\
\text { insurance policies dealing with price } \\
\text { and quantity risks as a "Revenue } \\
\text { and/or Income Stabilization Tool" }\end{array}$ \\
\hline "Normal" risk coverage & The CAP and MS responsibilities & $\begin{array}{l}\text { Support the creation of savings ac- } \\
\text { counts based on DPs in recognizing } \\
\text { some taxes as "national co-financing", }\end{array}$ \\
\hline $\begin{array}{l}\text { Openness to move from } \\
\text { constrained principles to } \\
\text { applied projects }\end{array}$ & $\begin{array}{l}\text { The administrative process for } \\
\text { monitoring innovation. Self- } \\
\text { censorship for experimentation }\end{array}$ & $\begin{array}{l}\text { Support field tests as real options on } \\
\text { the future of the EU farm risk man- } \\
\text { agement. Experience monitoring }\end{array}$ \\
\hline $\begin{array}{l}\text { Low experience of risk } \\
\text { management toolkit }\end{array}$ & $\begin{array}{c}\text { Lack of know-how, lack of ade- } \\
\text { quate database, and lack of } \\
\text { organization }\end{array}$ & $\begin{array}{c}\text { Create an experience curve in support- } \\
\text { ing a structured portfolio of field tests } \\
\text { with adequate evaluation }\end{array}$ \\
\hline $\begin{array}{l}\text { The additive umbrella prin- } \\
\text { ciple of the EU/MS/region }\end{array}$ & $\begin{array}{l}\text { Restrictive interpretation of inter- } \\
\text { national, EU and MS regulations }\end{array}$ & $\begin{array}{l}\text { Remove all current constraints on } \\
\text { field tests that could be adjusted later. } \\
\text { Flexible interpretation of constraints }\end{array}$ \\
\hline $\begin{array}{c}\text { Research, development, and } \\
\text { training }\end{array}$ & $\begin{array}{l}\text { Investment is required for design- } \\
\text { ing and implementing instruments, } \\
\text { creating common parameters, } \\
\text { assessing and pricing risks, train- } \\
\text { ing and education }\end{array}$ & $\begin{array}{l}\text { Create long-term collaborative net- } \\
\text { works of European Universities with } \\
\text { research and transfer expertise. De- } \\
\text { velop educational programmes }\end{array}$ \\
\hline Financial flexibility & $\begin{array}{l}\text { Fixed EU budget and limits of co- } \\
\text { financing }\end{array}$ & $\begin{array}{c}\text { Create macro- and micro-flexible } \\
\text { funds (EU nested reserve funds and } \\
\text { saving accounts) with adequate partic- } \\
\text { ipative rates of DPs }\end{array}$ \\
\hline Regulatory framework & $\begin{array}{c}\text { Dichotomy between two pillars, } \\
\text { Lack of coordination }\end{array}$ & $\begin{array}{l}\text { Create an EU Risk Agency with ade- } \\
\text { quate goals, capacities, and means }\end{array}$ \\
\hline Capacity of implementation & $\begin{array}{l}\text { From long-term to short-term } \\
\text { objectives of the Agency }\end{array}$ & $\begin{array}{l}\text { Establish strategic goals. Design the } \\
\text { potential experience curve }\end{array}$ \\
\hline
\end{tabular}

Source: [Cordier 2014]. 
Recommendations voiced by Mathijs [2017] consider building adaptive capacities which make farms more resilient in undistorted markets. Furthermore, restriction of public support on market measures should be offered only as a temporary support to the costs of producer organizations under the Common Market Organization. Moreover, the authors propose that the EU Risk Management Policy (RMP) should be built on three axes: risk prevention, risk mitigation, and risk coping. The RMP should undergo transformation towards a policy in which most private and public assembled resources are spent on risk prevention and the least on coping with risk. Nevertheless, the share of government spending should be the smallest in prevention and the highest in risk coping. Mitigation should coincide with manageable risks, while risk coping corresponds with catastrophic risks.

Recommendations published in the EP study Comparative analysis of risk management tools supported by the US Farm Bill 2014 and the CAP 2014-2020 by Cordier (2014) consider 10 recommendations - see Table 2.

\subsection{Summary and conclusions}

Great differences between the US and the EU were evident in the importance of direct payments in the EU and the US policies. These differences evolve from the different farming cultures, approaches and historical development, and economic philosophy. Furthermore, the range of institutional instruments in risk management is more developed in the US than in the EU. The US has been designing and implementing agricultural risk management policies longer than the EU.

In the US, agricultural policy has seen a full shift from direct payments to programmes which secure farm incomes in the event of risks of natural and price cause. This approach is reflected in the design of titles/programmes to support agricultural insurance and income support which is offered to the US farmers. The funds devoted to this policy represent a major part of public spending in the context of the US agriculture. On the contrary, direct payments in the EU's CAP represent vital support for farmers and a certain source of income, regardless of the actual result of their work. Risk management tools in the current period as defined in the Regulation 1305/2013 of the European Parliament and the Council on rural development support offer to the MS limited scope to deploy. Only thirteen RDPs from over one hundred programmes are implemented within the EU Member States. Above all, the European Union's CAP 2020+ should form agricultural risk management strategy with uniform guidelines which take into consideration the individual aspects and specifics of Member States.

The diversity of approaches to risk management in agriculture in the world and the countries of the European Union reflects various risks that farmers face in different countries [Bardaji et al., 2015].

The Czech experience shows that the EU's CAP risk management is little acceptable for the big agricultural corporations. The perception of risks is differ- 
ent for big corporations and for family farms [Soliwoda et al., 2017], to which the CAP is primarily targeted.

Risk management policy should address the variability of agricultural income rather than its level. The current risk management setting is too fragmented because it attaches little attention to building long-term resilience while paying too much attention to addressing short-term volatility. Creating resilience involves reducing farmers' exposure to risks. It is necessary to formulate measures compatible with incentives and measures promoting good agricultural technology and soil care. An important principle is a possibility for farmers to decide individually which tools they want to implement.

\section{References}

1. Agricultural Markets Task Force (2016). Improving market outcomes - Enhancing the position of farmers in the supply chain, Brussels.

2. Bardaji, I., Garrido, A., Blanco, I., et al. (2015). State of play of risk management tools implemented by members states during the period 2014-2020: national and European frameworks. European Parliament Study, Brussels.

3. Bureau, J.C. (2012). Latest U.S. Farm bill development, European Parliament, Brussels.

4. Cordier, J. (2015). Comparative analysis of risk management tools supported by the 2014 Farm Bill and the CAP 2014-2020. European Parliament Study, Brussels.

5. Johansson, R. (2016). Risk management: Lessons from the US Farm Bill. Presentation at the 2016 EU Agricultural Outlook Conference, Brussels.

6. Mathijs, E. (2017). Managing volatility and risk in the CAP. (Appendix 3). In Buckwell, A. et al. 2017. CAP - Thinking Out of the Box: Further modernization of the CAP - why, what and how? RISE Foundation, Brussels.

7. OECD (2011). A policy framework for risk management in agriculture, in Managing Risk in Agriculture: Policy Assesment and Design, OECD Publishing.

8. Regulation (EU) No. 1305/2013 of the European Parliament and of the Council of 17 December 2013 on support for rural development by the European Agricultural Fund for Rural Development (EAFRD) and repealing Council Regulation (EC) No 1698/2005“'. OJ L 347, 2013.

9. Report on Agriculture of the Czech Republic (Zpráva o stavu zemědělství ČR za rok 2016). Ministerstvo zemědělství, Praha 2017.

10. Soliwoda, M., Špička, J., Vilhelm, V., Pawłowska-Tyszko, J., Gorzelak, A. (2017). Is there a relationship between the prevailing model of agriculture and the structure of the crop and livestock insurance markets? Studies in Agricultural Economics.

11. Špička, J., Vilhelm, V. (2012). Risk management issues in the Czech agricultural holdings (Problematika řízení rizik $\mathrm{v}$ zemědělských podnicích ČR) ÚZEI 109/2012, Praha.

12.Vilhelm, V., Špička, J., Valder, A. (2015). Public Support of Agricultural Risk Management - Situation and Prospects. Agris on-line Papers in Economics and Informatics: Volume VII Number 2, Praha. 